\title{
The effect of heat and disinfectants on the viability of infectious bursal disease virus
}

\author{
Harimurti Nuradji ${ }^{1 *}$, Rahmat Setya Adji ${ }^{1}$ and Qadrina Ayu Besticia ${ }^{1}$ \\ ${ }^{1}$ Indonesian Research Center for Veterinary Sciences, Ministry of Agriculture Indonesia.
}

\begin{abstract}
Infectious Bursal Disease (IBD) has been reported in Indonesia since 1983 and has become an endemic disease. IBD virus is known to be quite resistant to physical and chemical reagents compared to other viruses, causing this disease is hard to be eradicated. This study aims to evaluate the effect of heat and disinfectants on the viability of the IBD virus. This study was conducted using a local isolate of IBDV obtained from IRCVS. The virus was exposed to heat and disinfectant. Heat treatment was conducted by exposing the virus to $56^{\circ} \mathrm{C}$ and $60^{\circ} \mathrm{C}$ for $30,60,120$, and 300 minutes. Similarly, the virus was also treated with two disinfectants, virkon and sodium hypochlorite (bleach) for 30, 60, 120, and 300 minutes with different concentrations. Results showed that the virus can be inactivated at a temperature of $80^{\circ} \mathrm{C}$ and $56^{\circ} \mathrm{C}$ for 120 and 300 minutes, respectively. Virkon at a concentration of 1:200 and 1:400 was able to inactivate the virus at 30, 60,120 , and 300 minutes, while sodium hypochlorite $0.5 \%$ requires at least 60 minutes to inactivate the virus.
\end{abstract}

\section{Introduction}

Infectious bursal disease or Gumboro disease is a contagious chicken disease that mostly generated severe clinical signs in young chickens at the ages of 4 to 6 weeks [1]-[3]. This disease causes high morbidity and mortality up to $90-100 \%$ in young chickens [4]-[6], although the outcome varies depending on several factors [3]. This disease is caused by a virus belonging to the genus Avibirnavirus, family Birnaviridae [2], [7]. It has linear doublestranded RNA and two structural proteins, VP2 and VP3, also VP4 as a serine protease [8].

Interestingly, this virus infects the lymphoid organs, primarily the bursa of Fabricius, although other immune organs are also involved [9]. As a result, infected chickens are more susceptible to other disease infections [1], [9]. Two serotypes of IBDV have been reported, serotype 1 which is pathogenic in chickens, and serotype 2 which is reported in turkey, duck, and chicken [7].

The infectious bursal disease was first reported in Indonesia in 1983, in Sawangan Bogor [10]. Since then the virus has spread and become endemic in almost all provinces in Indonesia. Vaccination is commonly used for preventing the disease [4]. Nevertheless, there are many causes of the diseases are reported. Compared to other viruses, the IBD virus is hard to be eradicated. Benton et al. [11] reported that IBDV can remain viable after being

\footnotetext{
*Corresponding author: harimurti.nuradji@gmail.com
} 
heated at $56^{\circ} \mathrm{C}$ for 5 hours. Similarly, a previous study is also reported that IBD virus is still viable in the environment for 122 days inside the chicken house and 52 days in feed and water [12]. The viability of the virus is likely due to the structure of the virus which is quite resistant to the environment [4]. Therefore, proper use of disinfectants and treatment is required to eradicate the virus. This study aims to evaluate the effect of heat treatment and disinfectants against a local strain of IBD virus.

\section{Materials and Methods}

\subsection{Embryonated chicken eggs}

Specific-pathogen-free (SPF) embryonated chicken eggs were used for the propagation of the viral stock. Specific-antibody-negative (SAN) embryonated chicken eggs were used for virus isolation.

\subsection{Virus}

Infectious Bursal Disease virus used was IBD Dramaga which is a local isolate of IBD virus collection of the Indonesian Research Center of Veterinary Science, Bogor. The virus was propagated in 9-11 days old specific pathogen-free (SPF) embryonated chicken eggs according to the procedure from OIE [2]. Briefly, $0,1 \mathrm{ml}$ of IBD virus was inoculated into the chorioallantoic membrane of SPF eggs. Infected embryonated chicken eggs were incubated in an incubator at $37^{\circ} \mathrm{C}$ for 4 days and observed daily. The chorioallantoic and allantoic fluid was harvested and collected for further testing. Titration of the virus was conducted in Vero cell following the procedure from OIE [13], [14]. Briefly, around $0.1 \mathrm{ml}$ of the virus was titrated in PBSA from $10^{-1}$ to $10^{-10}$, around $0.1 \mathrm{ml}$ of this dilution was added into 96 well plates with Vero cell suspension on it. Infected cells were incubated in $\mathrm{CO} 2$ Incubator at $37 \mathrm{C}$ for 4 days and observed daily. A titer of the virus was calculated following the procedure from Reed and Muench [15].

\subsection{Effect of heat on the viability of the IBD virus}

Around $1 \mathrm{ml}$ of virus suspension containing $10^{4} \mathrm{TCID}_{50} / 0.1 \mathrm{~mL}$ of IBD virus was exposed to two different temperatures in a water bath: $56^{\circ} \mathrm{C}$ and $80^{\circ} \mathrm{C}$ for $30,60,120$, and 300 minutes. The control virus was not treated but leave at room temperature for the same exposure time. The treated and control virus was inoculated into the chorioallantoic membrane of SAN eggs. Inoculated eggs were incubated at $37 \mathrm{C}$ for 7 days and observed daily. All dying and dead eggs were recorded.

\subsection{Effect of disinfectants on the viability of the IBD virus}

Two chemical disinfectants, Virkon ${ }^{\circledR}-\mathrm{S}$ (Antec ${ }^{\mathrm{TM}}$ International, UK) and sodium hypochlorite $0.5 \%$ were used in this study. Virkon was diluted with distilled water following the manufacturer's recommendation with the concentration of 1:200 and 1:400. The exposure time was $30,60,120$, and 300 minutes, respectively. The treated and control virus was inoculated into the chorioallantoic membrane of SAN eggs. Inoculated eggs were incubated at $37 \mathrm{C}$ for 7 days and observed daily. All dying and dead eggs were recorded. 


\subsection{Evaluation of treatment}

All the inoculated eggs either dead or survived eggs were stored at $4^{0} \mathrm{C}$ before being observed and tested. The eggs were opened and checked for the presence of a lesion. The inactivation of the virus by heating and disinfectant treatments is indicated by the presence of the lesions.

\section{Result and Discussion}

Infectious bursal disease or Gumboro disease is commonly reported in a poultry farm in Indonesia. Vaccination is mostly used by farmers to prevent the disease. However, cases are still reported to occur. This is likely due to the viability of the virus which is more resistant than other viruses. Results of the study show that at $56^{\circ} \mathrm{C}$, the IBD virus remained viable until 120 minutes/2 hours exposure, but was inactivated after 300 minutes. At $80^{\circ} \mathrm{C}$, the virus was inactivated after 120 and 300 minutes of treatment (Table 1). A shorter time is required to inactivate the IB virus with higher temperatures. This is in line with a previous study showing that IBD virus was able to be inactivated at 2 hours at a temperature of $56^{0} \mathrm{C}$ [11]. Similarly, a study by also showed that the virus was non-active at a temperature above $42^{\circ} \mathrm{C}$ [16]. Interestingly, compared to other avian viruses, IBD virus was more resistant. Avian Influenza was able to be inactivated in 30 minutes at $56^{\circ} \mathrm{C}$ [17], Infectious bronchitis was able to be inactivated in 90 minutes at $56^{\circ} \mathrm{C}$ [18]. Newcastle disease was only inactivated for 15 minutes at $54-58^{0} \mathrm{C}$ [19]. No egg embryo died showed that there is no bacterial contamination.

Table 1. Effect of heat treatment on the viability of IBD virus

\begin{tabular}{cccc}
\hline Temperature & $\begin{array}{c}\text { Exposure time } \\
\text { (minutes) }\end{array}$ & $\begin{array}{c}\text { Embryonic } \\
\text { death }\end{array}$ & Lesion \\
\hline \multirow{2}{*}{$56^{0} \mathrm{C}$} & 30 & --- & +++ \\
& 60 & --- & +++ \\
& 120 & --- & +++ \\
\multirow{3}{*}{$80^{\circ} \mathrm{C}$} & 300 & --- & --- \\
\hline 30 & 60 & --- & +++ \\
& 120 & --- & +++ \\
\hline & 300 & --- & --- \\
\hline
\end{tabular}

Note: +++ indicates the lesions were observed; -- - indicates no lesions were observed in the embryo.

The effect of disinfectants on the viability of IBD virus was presented in Table 2 . The virus remains viable after 30 minutes treated with $0.5 \%$ Sodium Hypochlorite, and was inactivated after 60, 120, and 300 minutes of treatment. Both concentrations of Virkon, 1:200 and 1:400, were able to inactivate the IBD virus with $30,60,120$, and 300 minutes of treatment. This indicates the potential use of sodium hypochlorite which is commonly used for laundry purposes to inactivate the IBD virus and decontamination, although proper contact time is required. The effectiveness of Virkon to inactivate the virus agrees with a previous study that showed Virkon was effective to inactivate the IBD virus [20]. 
Table 2. Effect of disinfectant treatment on the viability of IBD virus

\begin{tabular}{lccc}
\hline \multicolumn{1}{c}{ Temperature } & $\begin{array}{c}\text { Exposure time } \\
\text { (minutes) }\end{array}$ & $\begin{array}{c}\text { Embryonic } \\
\text { death }\end{array}$ & Lesion \\
\hline \multirow{3}{*}{ Sodium Hypochlorite } & 30 & --- & +++ \\
$0.5 \%$ & 60 & --- & --- \\
& 120 & --- & --- \\
\hline \multirow{3}{*}{ Virkon $1: 200$} & 300 & --- & --- \\
& 30 & --- & --- \\
& 60 & --- & --- \\
Virkon $1: 400$ & 120 & --- & --- \\
& 300 & --- & --- \\
& 30 & --- & --- \\
\hline
\end{tabular}

Note: +++ indicates the lesions were observed.; --- indicates no lesions were observed in the embryo.

The infectious bursal disease is known to be more resistant to physical and chemical treatments compared to the other avian viruses. Thus, it is quite difficult to control the disease on the farm due to the viability of the virus in the environment. Proper use of disinfectants and physical treatment can be implemented to kill the virus.

\section{Conclusion}

The infectious bursal disease was inactivated by heating at 56 and $80 \mathrm{C}$ for at least 300 and 120 minutes, respectively. Sodium hypochlorite $0.5 \%$ was able to inactivate the virus with 60 minutes contact time, while Virkon with the concentration of 1:200 and 1:400 was able to inactivate the virus for $30,60,120$, and 300 minutes exposure. This study showed that due to its resistance, proper use disinfection process and physical treatment are required to inactivate the virus. Further study is required to evaluate its activity on the virus in organic materials such as manure and soil.

We would like to thank Indonesian Research Centre for Veterinary Science, research staff Kusmaedi, Agus Winarsongko, Ani Purwany for their assistance.

\section{References}

1. S. Dey, D. C. Pathak, N. Ramamurthy, H. K. Maity, and M. M. Chellappa, Vet. Med. 10, 85-97 (2019). DOI: 10.2147/VMRR.S185159.

2. OIE, Infectious Bursal Disease, Terr. Anim. Heal. Code, (2018)

3. T. P. van den Berg, Acute Infectious Bursal Disease in Poultry : a Review, Avian Pathol 29, 3, 175-194 (2000)

4. J. K. Rosenberger, Y. M. Saif, and D. J. Jackwood, "Infectious Bursal Disease," in $A$ Laboratory Manual for The Isolation and Identification of Avian Pathogens, 4th ed., D. E. Swayne, J. R. Glisson, M. W. Jackwood, J. E. Pearson, and W. M. Reed, Eds. (American Association of Avian Pathologists, New Bolton Centre, 1998)

5. H. B. Aliyu, L. Sa'idu, A. Jamilu, A. D. Andaman, and S. O. Akpavie, Outbreaks of virulent infectious bursal disease in flocks of battery cage brooding system of 
commercial chickens, J. Vet. Med. 2016 (2016)

6. T. P. Van den Berg et al., Avian Pathol. 33, 5, 470-476 (2004)

7. P. D. Lukert and Y. M. Saif, "Infectious Bursal Disease," in Diseases of Poultry, 11th ed., Y. M. Saif, H. J. Barnes, and J. R. Glisson, Eds. (Iowa State University Press, Ames, 2003), pp. 161-179

8. H. Müller, M. R. Islam, and R. Raue, Vet. Microbiol. 97, 1-2, 153-165, (2003)

9. T. P. Van den Berg, N. Eterradossi, D. Toquin and G. Meulemans, Rev. Sci. Tech. 19, 2, 509-543 (2000)

10. L. Parede et al., Penyakit Hewan 26, 47, 20-24, (1994)

11. W. J. Benton, M. S. Cover, J. K. Rosenberger, R. S. Lake, Avian Dis. 11, 3, 438-445, (1967)

12. H. Müller, E. Mundt, N. Eterradossi and M. R. Islam, Avian Pathol. 41, 2, 133-139 (2012)

13. OIE, Newcastle disease (Infection with Newcastle disease virus), OIE Terr. Man., (2018)

14. P. Villegas, Titration of biological suspensions, A Lab. Man. Isol. Identif. avian Pathog., (1998), pp. 248-254

15. L. J. Reed and H. Muench, A simple method of estimating fifty percent endpoints, Am. J. Epidemiol. 27, 493-497 (1938)

16. S. Rani and S. Kumar,Biologicals, 43, 6, 515-518 (2015)

17. M. A. Shahid, M. Abubakar, S. Hameed, and S. Hassan, Virol. J. 6, 1, 38 (2009), DOI: 10.1186/1743-422X-6-38

18. K. Otsuki, H. Yamamoto, and M. Tsubokura,Arch. Virol. 60, 1, 25-32 (1979)

19. C. M. Chu, Epidemiol. Infect. 46, 3, 247-251 (1948)

20. J. Guan, M. Chan, B. W. Brooks and L. Rohonczy, Avian Dis. 58, 2, 249-254 (2014), DOI: $10.1637 / 10697-101713-$ Reg.1 